\title{
ICP-MS Determination of Lead Levels in Autopsy Liver Samples: An Application in Forensic Medicine
}

\author{
Enes Arica ${ }^{a}$, Bayram Yuksel $^{\mathrm{b}}$, Ismail Yenerc, Ibrahim Dolak ${ }^{\mathrm{d}}$, Ertugrul Gok ${ }^{\mathrm{e}}$, and Eyup Yilmaz \\ ${ }^{a}$ Dicle University, Medical Faculty, Department of Forensic Medicine, Diyarbakır, Turkey \\ ${ }^{b}$ Giresun University, Espiye Vocational School, Espiye 28600, Giresun, Turkey \\ ${ }^{c}$ Dicle University, Faculty of Pharmacy, Diyarbakır, Turkey \\ ${ }^{d}$ Dicle University, Vacotional School of Technical Sciences, Diyarbakır, Turkey \\ e Turkish Ministry of Justice, Council of Forensic Medicine, Samsun Branch Office, Samsun, Turkey \\ f Turkish Ministry of Justice, The Council of Forensic Medicine, Gaziantep Branch Office, Gaziantep, Turkey
}

\section{INTRODUCTION}

Air, water, and soil contamination are the basis of environmental problems. The fact that the environment is increasingly dangerous to human health due to pollution, urbanization, and especially industrial development has raised the contact with heavy metals not only for humans but all living things $(1,2)$. Lead $(\mathrm{Pb})$ is an abundant and functional metal which has been utilized since ancient times. This non-essential element has been extensively dispersed into nature and human exposure to $\mathrm{Pb}$ has increased (3). However, in most countries, elimination of lead from water lines, food packaging and paint as well as the use of lead-free petroleum products has diminished exposure to lead in recent years (4). In 2006, the International Agency for Research on Cancer (IARC) has classified lead compounds and inorganic lead as "Group 2A" probably carcinogenic to humans (5). Depending on exposure and duration, lead compounds have toxic effects on human health which cause enzyme inhibition resulting in significant pathological conditions or death (6). Peripheral neuropathy and hypertension are the major concerns in adults including the immune, skeletal, nerve, andrenal endocrine systems, and the respiratory tract (7). Even at low levels of exposure, haeme synthesis and other biochemical mechanisms can be damaged and neurobehavioural and psychological activities are weakened (8-10).

*Correspnding author.

E-mail: bayram.yuksel@giresun.edu.tr Tel: +905056283792

\section{ABSTRACT}

The objective of this study was to develop and validate a senstitive ICP-MS method with no gas mode for the determination of $\mathrm{Pb}$ levels in autospy liver samples collected from patients in Diyarbakır, Turkey. The microwave-assisted acid digestion procedure was optimized and applied to accurately weighed dry liver samples. The method showed linearity in the range of $0-100 \mu \mathrm{g} / \mathrm{kg}$ with a detection and quantification limit of 0.72 $\mu \mathrm{g} / \mathrm{kg}$ and $2.18 \mu \mathrm{g} / \mathrm{kg}$, respectively. The calibration graph was characterized with excellent correlation coefficients $(\mathrm{r}=0.9997)$ for $\mathrm{Pb}$ determination. Certified reference material was used to validate the method in terms of accuracy, precision, and recovery. Good agreement was obtained between the certified values and the measured $\mathrm{Pb}$ concentrations. Percent recovery and precision for $\mathrm{Pb}$ was calculated at $99.5 \%$ and $4.29 \%$, respectively. In the autopsy liver samples, the $\mathrm{Pb}$ levels ranged from $106.83 \mu \mathrm{g} / \mathrm{kg}$ to 1932.08 $\mu \mathrm{g} / \mathrm{kg}$ and the mean $\mathrm{Pb}$ levels were found at $375.24 \pm 325.46$ $\mu \mathrm{g} / \mathrm{kg}$. As a result of the statistical analysis, the occupation, smoking habit, settlement, gender, and age appeared to have an effect on the $\mathrm{Pb}$ levels in the autopsy liver samples. The procedure described is relatively simple, precise, and applicable for routine toxicological $\mathrm{Pb}$ determination in human tissue.

Inductively coupled plasma mass spectrometry (ICP-MS) is one of the most sensitive analytical techniques and provides the simultaneous determination of many heavy metals at ultra-trace levels in the different sample matrices (11). The first ICP-MS instrument was commercially marketed in 1983 and consists of six basic parts: sample input, plasma, sampling interface, ion directors, quadruple (mass separation part) and detector part (12).

The main goal of the present study was to develop and validate a senstitive ICP-MS method with no gas mode for the dermination of $\mathrm{Pb}$ levels in autospy liver samples collected from patients in Diyarbakir, Turkey. In addition, it was also investigated whether occupation, smoking habit, settlement, gender and age has an effect on the $\mathrm{Pb}$ levels in autopsy liver samples.

\section{EXPERIMENTAL}

\section{Instrumentation}

The measurements were performed using a Model 7700x ICP-MS (Agilent Corporation, USA). The operating parameters of the ICP-MS system are listed in Table I.

\section{Standard Solutions and Reagents}

Multi-element calibration standard 2A solutions containing 100 $\mathrm{mg} / \mathrm{L}$ lead and an ICP-MS internal standard mixture containing ${ }^{209} \mathrm{Bi}$ at the concentration of $1000 \mathrm{mg} / \mathrm{L}$ were purchased from Agilent Corporation, USA. Nitric acid $\left(\mathrm{HNO}_{3}\right.$, $65 \% \mathrm{v} / \mathrm{v}$ ) was obtained from Merck (Darmstadt, Germany). Ultrapure water (Merck Millipore Direct-Q8, Germany) with a resistivity of $18 \mathrm{M} \Omega \cdot \mathrm{cm}$ was used to prepare the solutions for the experimental 
TABLE I

Operating Parameters for ICP-MS System

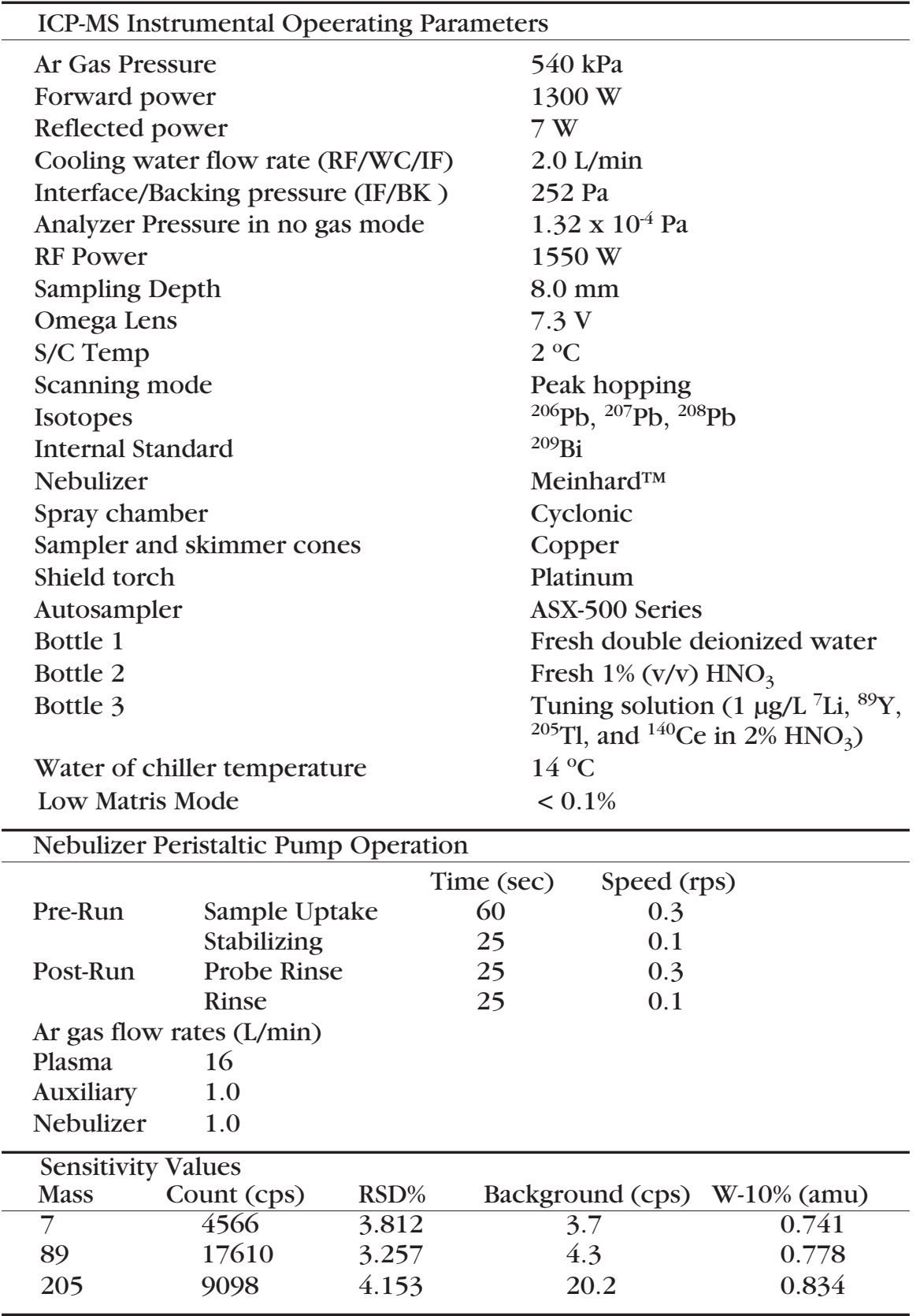

process. Argon gas with a purity of 99.999\% was bought from a local supplier (Linde Gaz, Diyarbakır, Turkey). The certified reference material (CRM) used for validation of the method was ERM ${ }^{\circledR}$-BB 18 Pig Kidney (Environmental Resource Management, Brussels, Belgium).
This study involved 100 mortal cases ranging from 18-90 years old. The liver samples were collected from the Ministry of Justice Diyarbakir Group Chairmanship of Council of Forensic Medicine in Diyarbakir, Turkey. The autospy

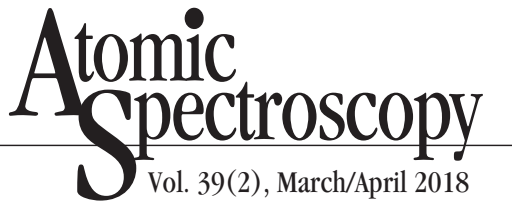

liver tissue samples were taken within a maximum of 24 hours after the death certificate was issued. The samples were put into 50-mL polypropylene tubes and preserved in the deep-freezer at $-25^{\circ} \mathrm{C}$ until pretreatment before analysis. This study was ethically approved by the Dicle University Medical Faculty Ethics Comittee for Noninterventional Studies (Decision No.: 04/25.12.2013). This work was also approved by the Turkish Ministry of Justice Council of Forensic Medicine (Reference No.: 03.09.2013 and B.03.1.ATK.0.01.00.08/529, respectively) in terms of sample collection from the autopsy cases.

\section{Sample Preparation and Procedure}

The autopsy liver tissues were placed on the vitreous platform and kept in a drying oven at $75^{\circ} \mathrm{C}$ for 24 hours. After this step, the dried samples were accurately weighed, and the mean weight of the samples was $0.3584 \pm 0.1206 \mathrm{~g}$. Next, the samples were individually placed into temperature-resistant Teflon ${ }^{\circledR}$ tubes, pretreated by addition of $10 \mathrm{~mL}$ of $65 \%(\mathrm{v} / \mathrm{v})$ nitric acid, sealed and placed into the microwave system (CEM Mars Xpress, Matthews, NC, USA) for digestion. The microwave temperature program is listed in Table II. The digested solutions were then diluted with ultra-pure water in 15-mL polypropylene tubes until the total volume of the samples reached $14 \mathrm{~mL}$. The acid-digested autopsy liver samples were stored

TABLE II

Temperature Program for Microwave Digestion

Max. Power $600 \mathrm{~W}$

Power $\quad 100 \%$

Ramp Time $10 \mathrm{~min}$

Pressure $\quad 350 \mathrm{psi}$

Temperature $\quad 200{ }^{\circ} \mathrm{C}$

Hold Time $10 \mathrm{~min}$ 
separately in the refrigerator at $4^{\circ} \mathrm{C}$ until the day of analysis. In order to prepare calibration standards at the concentrations of $1.0,5.0,10.0$, $25.0,50.0$, and $100.0 \mu \mathrm{g} / \mathrm{L}$, a 100 $\mu \mathrm{g} / \mathrm{mL}$ lead stock solution was diluted in $4 \%$ (v:v) $\mathrm{HNO}_{3}$. An internal standard mixture containing ${ }^{209} \mathrm{Bi}$ at the concentration of 1000 $\mathrm{mg} / \mathrm{L}$ (Agilent, USA)was manually diluted with the use of nitric acid $4 \%(\mathrm{v} / \mathrm{v})$ until the final concentration reached $100 \mu \mathrm{g} / \mathrm{L}$. Then, the final solution of the internal standard was automatically pumped to all solutions. All glassware was kept in $10.0 \%(\mathrm{v} / \mathrm{v})$ nitric acid for at least one night before the analysis.

\section{Optimization}

In order to achieve the best performance for this ICP-MS analysis, some important parameters were adjusted such as selection of concentration range in accordance with the elemental concentration in real liver samples and establishing linearity. The samples were injected (60 s, $0.3 \mathrm{rps}$ ) using a Meinhard ${ }^{\circledR}$ nebulizer with a chilled spray chamber. No flow injection valve was utilized, and the autosampler was directly set up to stay in the sampling position for the defined time. The argon plasma conditions were adjusted as forward power at $1300 \mathrm{~W}$ and reflected power of $7 \mathrm{~W}$. The nebulizer gas flow rate, auxilary and plasma gas flow rates were selected as 1.0, 1.0, and $16.0 \mathrm{~L} / \mathrm{min}$, respectively. Interface cones of nickel were used. The instrument was run in peak jumping mode while ${ }^{206} \mathrm{~Pb},{ }^{207} \mathrm{~Pb},{ }^{208} \mathrm{~Pb}$, and ${ }^{209} \mathrm{Bi}$ were scanned at three points per peak. The sum of the three lead isotopes was used for the calculations. For lead analysis in the autopsy liver samples, the dwell time was $0.07 \mathrm{~s} /$ point for lead and $0.02 \mathrm{~s} /$ point for $\mathrm{Bi}$, and the acquisition time was 0.30 $\mathrm{s} / \mathrm{mass}$ for lead and $0.15 \mathrm{~s} / \mathrm{mass}$ for $\mathrm{Bi}$. The method showed linearity in the range of $0-100 \mu \mathrm{g} / \mathrm{L}$ for lead
(Figure 1). The correlation coefficient ( $r$ ) and the equation of the calibration curve for lead were respectively found to be $r=0.9997$ and $\mathrm{Abs}=0.1264^{*} \mathrm{C}+0.0339$, where Abs stands for integrated absorbance and $\mathrm{C}$ is the lead concentration in $\mu \mathrm{g} / \mathrm{L}$.

\section{Method Validation}

To validate the method in terms of accuracy, precision, and recovery, the CRM ERM ${ }^{\circledR}$-BB 18, Pig Kidney was analyzed 10 times with triplicate measurements. The precision of the methods is expressed as the relative standard deviation (RSD) of 10 independent analyses of the CRM. The results were compared with the certified values for accuracy, precision, and recovery of the method. Good agreement was obtained between the certified values and the measured $\mathrm{Pb}$ concentrations. The percent recovery and precision for $\mathrm{Pb}$ were calculated as $99.5 \%$ and $4.29 \%$, respectively. The analytical results of the CRM are listed in Table III.

\section{Limit of Detection, Quantifica- tion, and Linearity}

According to the ICH guidelines (13-15), the limit of detection (LOD) and lowest limit of quantification (LOQ) were determined

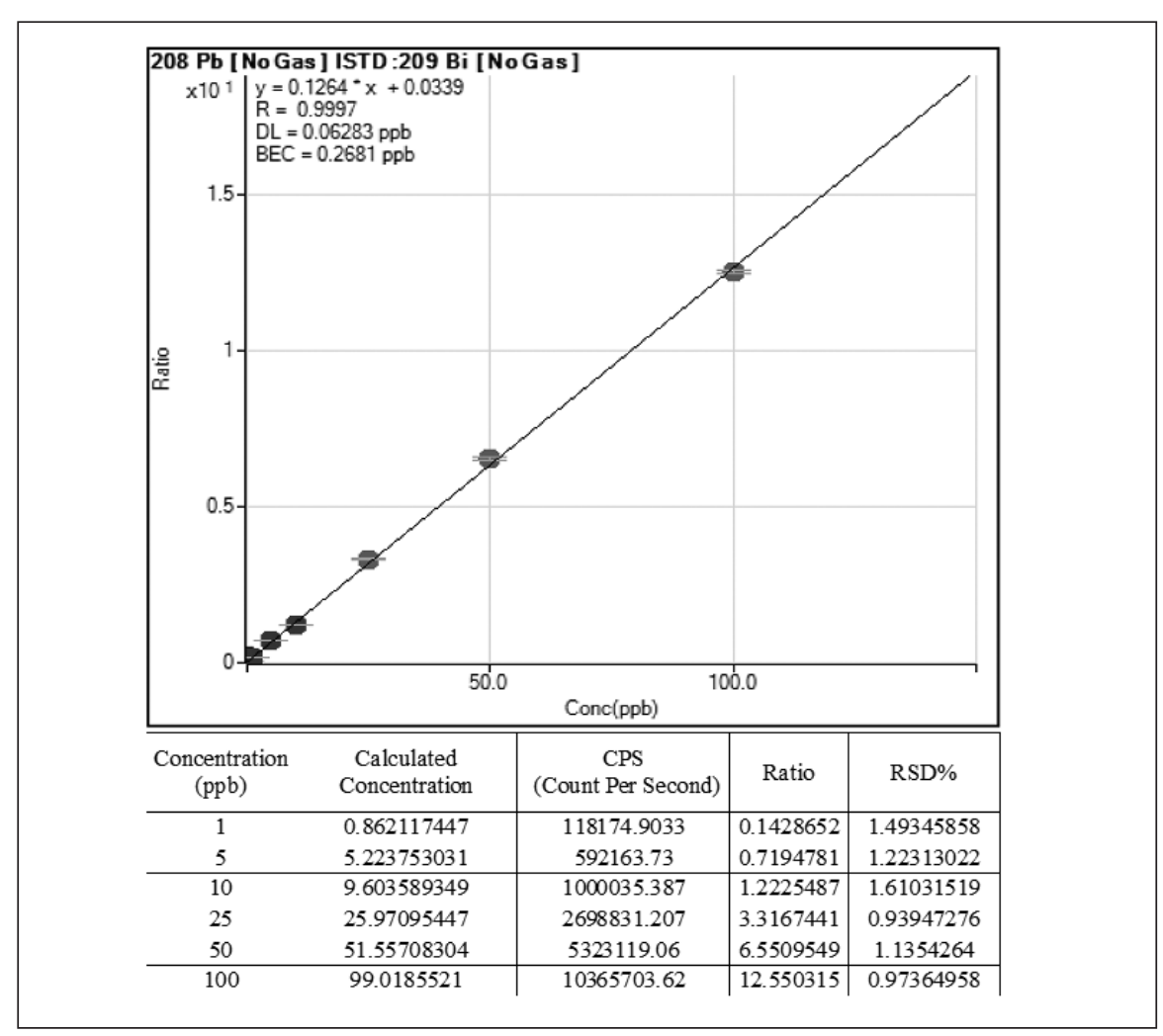

Fig 1. Calibration graph of Pb, performed by ICP-MS.

TABLE III

Analysis of Certified Reference Material

\begin{tabular}{lccccc}
\hline CRM & $\begin{array}{c}\text { Number } \\
\text { of Analyses } \\
(\mathrm{n})\end{array}$ & $\begin{array}{c}\text { Certified } \\
\text { Value } \\
(\mu \mathrm{g} / \mathrm{kg})\end{array}$ & $\begin{array}{c}\text { Measured } \\
\text { Value } \\
(\mu \mathrm{g} / \mathrm{kg})\end{array}$ & $\begin{array}{c}\text { Recovery } \\
(\%)\end{array}$ & $\begin{array}{c}\text { RSD } \\
(\%)\end{array}$ \\
\hline $\begin{array}{l}\text { ERM-BB186 } \\
\text { Pig Kidney }\end{array}$ & 10 & $0.040 \pm 0.005$ & $0.0389 \pm 0.0017$ & 99.5 & 4.29 \\
\hline
\end{tabular}


based on the standard deviation of the response and the slope of the calibration curve $(\mathrm{LOD}=3.3 \sigma / \mathrm{S}$, $\mathrm{LOQ}=10 \sigma / \mathrm{S}$, where $\sigma$ is the standard deviation of the response and $\mathrm{S}$ is the slope of the calibration curve). The LOD and LOQ for lead was equal to $0.72 \mu \mathrm{g} / \mathrm{kg}$ and 2.18 $\mu \mathrm{g} / \mathrm{kg}$, respectively. The limit of linearity (LOL), which is the concentration at which the calibration curve departs from linearity, was $100 \mu \mathrm{g} / \mathrm{L}$. The dynamic range refers to the concentration intervals from LOQ to LOL, and was found to be between $2.78 \mu \mathrm{g} / \mathrm{kg}$ to $100.0 \mu \mathrm{g} / \mathrm{kg}$ for lead. The schematic diagram of the dynamic range study is shown in Figure 2.

\section{Statistical Analysis}

The findings were statistically evaluated based on occupation (risky and unrisky), locality (rural and urban), smoking habit, age, and gender. The statistical analyses were peformed utilizing the Statistical Package for Social Sciences (SPSS) version 16.0 software for Windows ${ }^{\circledR}$. All results were expressed as the mean \pm standard deviation (SD) of the mean, and the normality of data distribution was assessed with the Kolmogorov-
Smirnov test. The differences of the continuous variables between the two groups were evaluated by the Student's $t$-test and the correlations between the parameters were described using the Pearson's test. The statistical significance was considered as $\mathrm{p}<0.05$.

\section{RESULTS AND DISCUSSION}

After exposure, lead accumulates in the soft tissue. According to autopsy studies, the liver appears to be the greatest depository of lead (33\%), followed by the kidney cortex and medulla, pancreas, ovary, spleen, prostate, adrenal gland, brain, fat, testis, heart, and skeletal muscles $(16,17)$. Biological observation for human exposure to $\mathrm{Pb}$ indicates an individual's recent body burden as an occasion of present and/or previous exposure. Therefore, the relevant choice of biomarkers and determination of $\mathrm{Pb}$ exposure are highly important in terms of health care management, public health decision-making, and primary prevention activities (18). The World Health Organization (WHO) recommended the permissible weekly intake of $\mathrm{Pb}$ as 25.0 $\mu \mathrm{g} / \mathrm{kg}$ (body weight) (19). Thus,

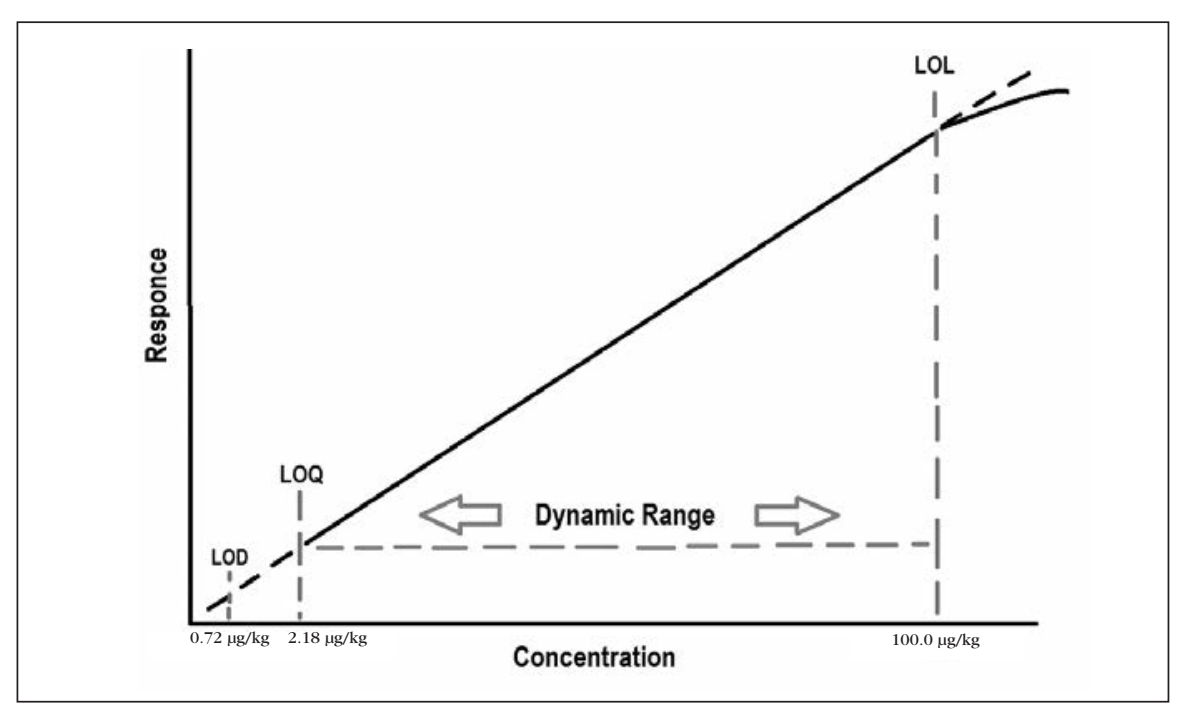

Fig 2. Schematic of dynamic range study. ICP-MS method for lead analysis in autopsy liver samples provided LOD, LOQ, and LOL equal to $0.72 \mu \mathrm{g} / \mathrm{kg}, 2.18 \mu \mathrm{g} / \mathrm{kg}$ and $100.0 \mu \mathrm{g} / \mathrm{kg}$, respectively.

\section{A}

for an adult at $70 \mathrm{~kg}$, the allowable intake of $\mathrm{Pb}$ is $250 \mu \mathrm{g} /$ day (20).

In this study, the $\mathrm{Pb}$ levels of 100 autopy liver samples were measured by ICP-MS and found to be between $106.83 \mu \mathrm{g} / \mathrm{kg}$ and $1932.10 \mu \mathrm{g} / \mathrm{kg}$. Thus, the mean $\mathrm{Pb}$ levels were $375.24 \pm 325.46 \mu \mathrm{g} / \mathrm{kg}$. As a result of the statistical analysis (see Table IV), occupation, smoking habit, living locality, gender, and age appeared to have an effect on the $\mathrm{Pb}$ levels in the autopsy liver samples. The mean liver lead content of the risky occupation group $(523.29 \pm 406.57 \mu \mathrm{g} / \mathrm{kg})$ was statistically higher than the unrisky occupation group $(280.59 \pm 216.16$ $\mu \mathrm{g} / \mathrm{kg})(\mathrm{p}=0.001 ; \mathrm{p}<0.001)$. The higher risk to lead exposure included drivers, cleaners, miners, and industrial workers. The effect of living in rural or urban areas on liver $\mathrm{Pb}$ levels was also investigated. It was found that the mean liver $\mathrm{Pb}$ concentration of individuals who had lived in urban areas (454.92 $\pm 374.14 \mu \mathrm{g} / \mathrm{kg}$ ) was significantly higher than for rural areas (301.69 $\pm 255.19 \mu \mathrm{g} / \mathrm{kg})(\mathrm{p}=0.018$; $\mathrm{p}<0.05)$. In an urban area, industrial pollution and occupational exposure risks are comparatively higher than for rural areas and is thus reflected in the.higher liver lead levels of individuals who had lived in urban rather than rural areas.

Since lead is one of the many chemicals found in cigarettes, smokers are easily exposed to lead. According to another finding of this study, the $\mathrm{Pb}$ levels in smokers $(455.95 \pm 366.92 \mu \mathrm{g} / \mathrm{kg}$ ) were significantly higher than for nonsmokers (254.18 $\pm 200.39 \mu \mathrm{g} / \mathrm{kg}, \mathrm{p}=0.002$; $\mathrm{p}<0.05)$. In addition, significantly higher values of $\mathrm{Pb}$ were found in males $(413.49 \pm 357.39 \mu \mathrm{g} / \mathrm{kg})$ than in females $(247.22 \pm 114.72 \mu \mathrm{g} / \mathrm{kg}$, $\mathrm{p}=0.031 ; \mathrm{p}<0.05)$. Furthermore, $\mathrm{a}$ positive correlation was observed between liver $\mathrm{Pb}$ levels and age. Hence, liver $\mathrm{Pb}$ levels increased significantly with age as well $(\mathrm{r}=+0.204$ and $\mathrm{p}=0.042 ; \mathrm{p}<0.05)$. 
Since all findings obtained from this study were carried out in Diyarbakır, Turkey, they will be a good reference for future studies in the assessment of lead levels in autopsy liver samples in other locations and nations.

\section{CONCLUSION}

ICP-MS has proven to be the optimal methodology for pursuing the lowest achievable detection limits and highest level of productivity in the $\mathrm{Pb}$ analysis of autopsy liver samples. In this work, the LOD, LOQ, and LOL values were equal to $0.72 \mu \mathrm{g} / \mathrm{kg}, 2.18 \mu \mathrm{g} / \mathrm{kg}$, and $100.0 \mu \mathrm{g} / \mathrm{kg}$, repectively. The percent recovery and precision for $\mathrm{Pb}$ was found at $99.5 \%$ and $4.29 \%$, respectively. The ICP-MS technique is almost free from interferences, relatively simple, precise, and applicable for routine postmortem toxicological $\mathrm{Pb}$ analysis.

\section{ACKNOWLEDGMENT}

This work was financially supported by the Dicle University Scientific Research Project Coordination Unit (BAP: Project Number 14-MYO-82).

Received May 29, 2017.

\section{REFERENCES}

1. S.L. Wong, and E.J. Lye, Health Rep. 19(4), 31 (2008).

2. L. Jarup, Occup Environ Med. 60(7), 461 (2003).

3. M.A. Smith. Lead in History. In: R. Lansdown and W. Yule, eds., The lead debate: The environmental toxicology and child health, London, UK, Croom Helm 7-24 (1984).

4. European Food Safety Authority Panel on Contaminants in the Food Chain, Scientific opinion on lead in food, EFSA J. 8, 1570-1717 (2010).

5. IARC (International Agency for Research on Cancer) Classified by the IARC Monographs, Volumes 1-102. (2012).

TABLE IV

Statistical Analysis ( $\mu \mathrm{g} / \mathrm{kg})$

\begin{tabular}{|c|c|c|c|c|}
\hline Groups & Minimum & Maximum & Mean \pm S.D. & $\mathrm{p}$ Value \\
\hline \multicolumn{5}{|l|}{ Occupation } \\
\hline $\begin{array}{l}\text { Unrisky } \\
(\mathrm{n}=61)\end{array}$ & 106.83 & 457.20 & $280.59 \pm 216.16$ & \multirow{2}{*}{$0.001^{* *}$} \\
\hline $\begin{array}{l}\text { Risky } \\
(n=39)\end{array}$ & 278.20 & 1932.08 & $523.29 \pm 406.57$ & \\
\hline \multicolumn{5}{|l|}{ Settlement } \\
\hline $\begin{array}{l}\text { Rural } \\
(n=52)\end{array}$ & 106.83 & 610.20 & $301.69 \pm 255.19$ & \multirow{2}{*}{$0.018^{*}$} \\
\hline $\begin{array}{l}\text { Urban } \\
(n=48)\end{array}$ & 235.80 & 1932.08 & $454.92 \pm 374.14$ & \\
\hline \multicolumn{5}{|l|}{ Smoking Habit } \\
\hline $\begin{array}{l}\text { Smoking } \\
(\mathrm{n}=60)\end{array}$ & 275.99 & 1932.08 & $455.95 \pm 366.92$ & \multirow{2}{*}{$0.002^{* *}$} \\
\hline $\begin{array}{l}\text { Non-Smoking } \\
(\mathrm{n}=40\end{array}$ & g 106.83 & 455.45 & $254.18 \pm 200.39$ & \\
\hline \multicolumn{5}{|l|}{ Gender } \\
\hline $\begin{array}{l}\text { Female } \\
(n=23)\end{array}$ & 106.83 & 608.10 & $247.22 \pm 114.72$ & \multirow[t]{2}{*}{$0.031^{*}$} \\
\hline $\begin{array}{l}\text { Male } \\
(n=77)\end{array}$ & 111.09 & 1932.08 & $413.49 \pm 357.39$ & \\
\hline
\end{tabular}

* p value $<0.05$

** p value $\leq 0.01$
6. R.A. Goyer, Environ. Health Perspect. 86, 177 (1990).

7. J. Liu, R.A. Goyer and M.P. Waalkes, Toxic Effects of Metals. C.D. Klaassen, Ed., Casarett \& Doull's Essentials of Toxicology: The Basic Science of Poisons, 7th ed., McGrawHill, New York, USA, 943-980 (2008).

8. Inorganic lead. Geneva, Switzerland, World Health Organization, Environmental Health Criteria, No. 165 (1995).

9. The nature and extent of lead poisoning in children in the United States: A report to Congress. Atlanta, GA, United States Department of Health and Human Services (1988).

10 G.W. Goldstein, Pediatric Annals 21(6), 384 (1992).

11. R.N. Rao and M.V.N.K. Talluri, J Pharm. Biomed. Anal. 43, 1 (2007).

12. Y. Ha, O.G. Tsay and D.G. Churchill, Monatsheft Chem. 142, 385 (2011).

13. International Conference on Harmonization (ICH) of Technical Requirements for the Registration of Pharmaceuticals for Human Use, Validation of Analytical Procedures: Methodology (ICB-Q2B) (1996).

14. B. Yüksel, Z. Kayaalti, D. KayaAkyüzlü, D. Tekin and T. Söylemezoglu, At. Spectrosc. 37(3), 114 (2016).

15. B. Yüksel, D. Kaya-Akyüzlü, Z. Kayaaltı, F. Özdemir, D. SöylemezGökyer, and T. Söylemezoglu, At. Spectrosc. 38 (2), 71 (2017).

16. P.S. Barry, Br. J. Ind. Med. 32, 119 (1975).

17. L. Patrick, Altern. Med. Rev. 11(1), 2 (2006).

18. F. Barbosa, J.E. Tanus-Santos, R.F. Gerlach and P.J. Parsons, Environ. Health Perspect. 113(12), 1669 (2005).

19. World Health Organization (WHO), International Programme on Chemical Safety (IPCS). Geneva, Switzerland, WHO Food Additives Series: 44 (2000).

20. M. Sharma, M. Maheshwari, S. Morisawa, Risk Anal 25(6), 1573 (2005). https://doi.org/10.1111/j. 1539-6924.2005.00683.x 